\title{
Large-scale migration of a school shark, Galeorhinus galeus, in the Southwestern Atlantic
}

\author{
Andrés J. Jaureguizar ${ }^{1,2}$, Federico Argemi ${ }^{3}$, Gastón Trobbiani ${ }^{4}$, Elbio D. Palma ${ }^{5,6}$ and \\ Alejo J. Irigoyen ${ }^{4}$
}

Knowledge of the spatial and temporal distribution patterns of chondrichthyans is critical for their effective management. In this study we report and analyze a large-scale latitudinal migration $(\sim 1,425 \mathrm{~km})$ of a female school shark in the Southwestern Atlantic shelf where it is currently classified as Critically Endangered. During the austral summer (February 15, 2015), ninety-four school sharks were captured (75 females and 19 males) and tagged with fin tags in Nuevo Gulf ( $\sim 42^{\circ} 43^{\prime} \mathrm{S}$, $64^{\circ} 53^{\prime} \mathrm{W}$, Argentina). A female of $112 \mathrm{~cm}$ total length was recaptured in Uruguayan shelf waters in the austral winter (August 17, 2015). This long displacement represents the first direct evidence to support Vooren and Lucifora's hypothesis of a single transnational population of Galeorhinus galeus in the Southwestern Atlantic. The good agreement found between the school shark habitat conditions (salinity 33-34, temperature $12-17^{\circ} \mathrm{C}$ ) and the warmer member of Subantarctic Shelf Waters suggests that the seasonal variation in school shark abundance within this region could be related to water masses movements.

Keywords: Argentina-Brazil, Distribution pattern, Habitat preference, Migration, Shelf water.

El conocimiento sobre los patrones de distribución espacio-temporal de los condrictios es crítico para su manejo efectivo. En este trabajo presentamos y analizamos una migración latitudinal de gran escala $(\sim 1.425 \mathrm{~km})$ de una hembra de cazón en la plataforma del Océano Atlántico Sudoccidental, donde está actualmente clasificada como Críticamente en Peligro. Durante el verano austral (15 de Febrero de 2015), 94 cazones fueron capturados (75 hembras y 19 machos) y señalados con marcas

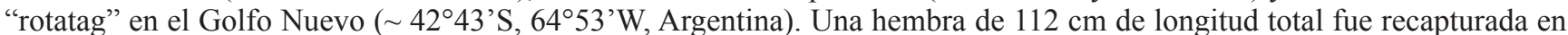
aguas de la plataforma uruguaya durante el invierno austral (17 de Agosto de 2015). Este gran desplazamiento representa la primera evidencia directa para apoyar la hipótesis de Vooren y Lucifora sobre una única población transnacional de Galeorhinus galeus en el Océano Atlántico Sudoccidental. La gran coincidencia encontrada entre las condiciones de hábitat para el cazón (salinidad 33-34, temperatura $12-17^{\circ} \mathrm{C}$ ) y el integrante más cálido del Agua de Plataforma Subantártica sugiere que la variación estacional en la abundancia del cazón dentro de esta región podría estar relacionada con el movimiento de las masas de agua.

Palabras claves: Aguas de plataforma, Argentina-Brazil, Patrón de distribución, Preferencia de hábitat, Migración.

\section{Introduction}

Galeorhinus galeus (Linnaeus, 1758) is a medium-sized shark that occurs in coastal and shelf temperate waters (Compagno et al., 2005; Ebert et al., 2013). A recent study (Chabot et al., 2015) has shown that there are at least five genetically differentiated populations (Africa, Australia, North and South America and Western Europe), with no genetic interconnectivity among them, possibly due to the long distances between different ocean basins and barriers related to temperature. In the Southwestern Atlantic (SWA), it inhabits in the Bonaerensean Biogeographic District,

${ }^{1}$ Comisión de Investigaciones Científicas de la Provincia de Buenos Aires (CIC), Calle 526 e/ 10- 11, CP 1900, La Plata, Argentina.

${ }^{2}$ Instituto Nacional de Investigación y Desarrollo Pesquero (INIDEP), Paseo Victoria Ocampo $\mathrm{N}^{\circ}$ 1, B7600EEP, Mar del Plata, República Argentina. ajj@inidep.edu.ar, ๑https://orcid.org/0000-0003-1916-8682 (corresponding author)

${ }^{3}$ Fundación Temaiken, Ruta 25, Km. 1, Escobar, Argentina. fargemi@temaiken.org.ar

${ }^{4}$ Centro para el Estudio de Sistemas Marinos (CESIMAR), Consejo Nacional de Investigaciones Científicas y Técnicas (CCT CENPAT - CONICET). Boulevard Brown 2915, (U9120ACD) Puerto Madryn, Chubut, Argentina. (GT) trobbiani@cenpat-conicet.gob.ar, (AJI) alejo@cenpat-conicet.gob.ar

${ }^{5}$ Instituto Argentino de Oceanografía, CONICET, Bahía Blanca, Argentina. uspalma@criba.edu.ar

${ }^{6}$ Departamento de Física, Universidad Nacional del Sur, Av. Alem 1253, B8000CPB, Bahía Blanca, Argentina. uspalma@criba.edu.ar 
within the Western Temperate South Atlantic Province (Menni et al., 2010), from $30^{\circ} \mathrm{S}$ (Brazil, Vooren, 1997) to $49^{\circ} \mathrm{S}$ (Argentina, Chiaramonte, 2015) and from the coastline to $400 \mathrm{~m}$ in the northern waters (Brazil, Klippel et al., 2016; Peres, Vooren, 1991) and up to $200 \mathrm{~m}$ in the southern area (Uruguay-Argentina, Menni et al., 2010) (Fig. 1A). Globally, this species is currently classified as Vulnerable, but in the SWA it is categorized as Critically Endangered and without major and urgent management measures its conservation status could become even worse (Walker et al., 2006).

In the SWA, the school shark has been proposed as a migratory species travelling seasonally between the Southern Brazilian Shelf and the Northern Argentine Shelf (Vooren, 1997; Fig. 1A). Off southern Brazil $\left(30^{\circ}-34^{\circ} \mathrm{S}\right)$, it is abundant at depths of $40-350 \mathrm{~m}$, and the seasonal pattern is characterized by a fall immigration with peaks during winter (June-September) and a spring emigration (OctoberNovember), being absent during the summer months (January and February) (Peres, Vooren, 1991). On this basis, Vooren (1997) hypothesized that the school sharks spend the austral winter in the northern region of their latitudinal range (off southern Brazil), and then migrate southwards to the Northern Argentine Shelf $\left(35^{\circ}-45^{\circ} \mathrm{S}\right)$ in the austral summer. This migration could be related to reproductive habits (giving birth in nursery areas) that putatively occur in the south (Vooren, 1997; Nion, 1999; Walker, 1999; Lucifora et al., 2004).

Lucifora et al. (2004) found that the patterns of occurrence, reproductive condition, and embryonic growth in the Northern Argentine Shelf waters (San Blas Bay, Fig. 1A) are complementary to those from the Southern Brazilian Shelf, supporting the hypothesis that there is a single large population of school sharks in the SWA. Recently, some evidence collected within the southern part of the SWA shelf sustains the north/south migration pattern. Two specimens tagged near Nuevo Gulf $\left(42^{\circ} 43^{\prime} \mathrm{S}\right)$ were recaptured, one off Anegada Bay $\left(40^{\circ} 12^{\prime} \mathrm{S}\right)$ and the other one near Mar del Plata $\left(\sim 38^{\circ} \mathrm{S}\right)$. The latter one is the longest northward travel registered so far $(\sim 847 \mathrm{~km})$ in the SWA, and occurred from late austral summer (March) to late austral spring (December) (Irigoyen et al., 2015, Fig. 1A).

In this study, we provide new evidence on the largescale latitudinal migration of school sharks along the SWA shelves, and discuss the relationship between the observational data and the distribution and circulation of water masses in this area.

\section{Material and Methods}

Study area. The region of interest extends from Nuevo Gulf $\left(\sim 42^{\circ} 30^{\prime} \mathrm{S}\right.$, Argentina) to the northern sector of the Southern Brazilian Shelf $\left(\sim 30^{\circ} \mathrm{S}\right.$, Fig. 1A). The offshore circulation in this region is dominated by two intense western boundary currents flowing in opposite directions: the Malvinas Current (MC), a northward flowing cold and relatively fresh detachment of the Antarctic Circumpolar Current, and the
Brazil Current (BC), a southward flowing warm and salty wind-driven current (Piola, Matano, 2001). The MC and the $\mathrm{BC}$ collide at approximately $38^{\circ} \mathrm{S}$ creating a region of intense mesoscale variability known as the Brazil/Malvinas Confluence (BMC) (Matano et al., 1993). The circulation over the shelf reflects the influence of the western boundary currents, which contribute to the formation of a northward flow of cold and fresher waters in the south and a southward flow of warm and saltier waters in the north (Palma et al., 2008; Matano et al., 2010). Interestingly, the northward shelf flow of Northern Argentine Shelf waters (mainly Subantarctic Shelf Waters) overshoots the BMC location and meet the southward flowing subtropical waters near $33^{\circ} \mathrm{S}$, well inside the Southern Brazilian Shelf, generating a density compensated front, known as the Subtropical Shelf Front (Piola et al., 2000, Fig. 1A).

Sampling procedure. A diurnal fishing cruise was developed in Nuevo Gulf waters on February 15, 2015 to tag school sharks. This cruise was within the project "Habitat use and migration patterns of large sharks in coastal waters of the Southwest Atlantic Ocean (SWA)", initiated jointly by researchers from the CIC-INIDEP (Comision de Investigaciones Científicas; Instituto Nacional de Investigación y Desarrollo Pesquero), CONICET-CENPAT (Consejo Nacional de Investigaciones Científicas y Técnicas; Centro Nacional Patagónico), and Temaiken Foundation. The study area is part of Valdés Península, a World Heritage site in terms of their relevance from the point of view of conservation, and in particular for the large concentrations of birds and marine mammals.

School sharks were captured in waters between 80 and $110 \mathrm{~m}$ depth during the diurnal fishing trip (Fig. 1A) and tagged with fin tags (standard Rototag). The Rototag is a two-piece plastic cattle ear tag that is inserted through the first dorsal fin (Fig. 2). To capture the sharks, an 800 $\mathrm{m}$ bottom longline with 110 hooks ("Goldfish-Octopus Hook" type 10/0 92553 series) was set from a semi-rigid boat ( $4.9 \mathrm{~m}$ length) for $120 \mathrm{~min}$ with hooks baited with chub mackerel (Scomber colias). The setting time was established based on previous tests in order to ensure the welfare of captured individuals (Irigoyen et al., 2015). Upon capture, sharks were sexed and their total length measured. During the fishing sessions the surface water temperature was measured.

Abbreviations. SWA: Southwestern Atlantic Ocean, BMC: Brazil/Malvinas confluence, MC: Malvinas Current. BC: Brazil Current, SASW: Subantarctic Shelf Water, CIC: Comisión de Investigaciones Científicas de la Provincia de Buenos Aires, INIDEP: Instituto Nacional de Investigación y Desarrollo Pesquero, CONICET-CENPAT: Consejo Nacional de Investigaciones Científicas y Técnicas; Centro Nacional Patagónico, DINARA: Dirección Nacional de Recursos Acuáticos, TL: Total length, SST: Sea Surface Temperature, T: Temperatures, S: salinity. 

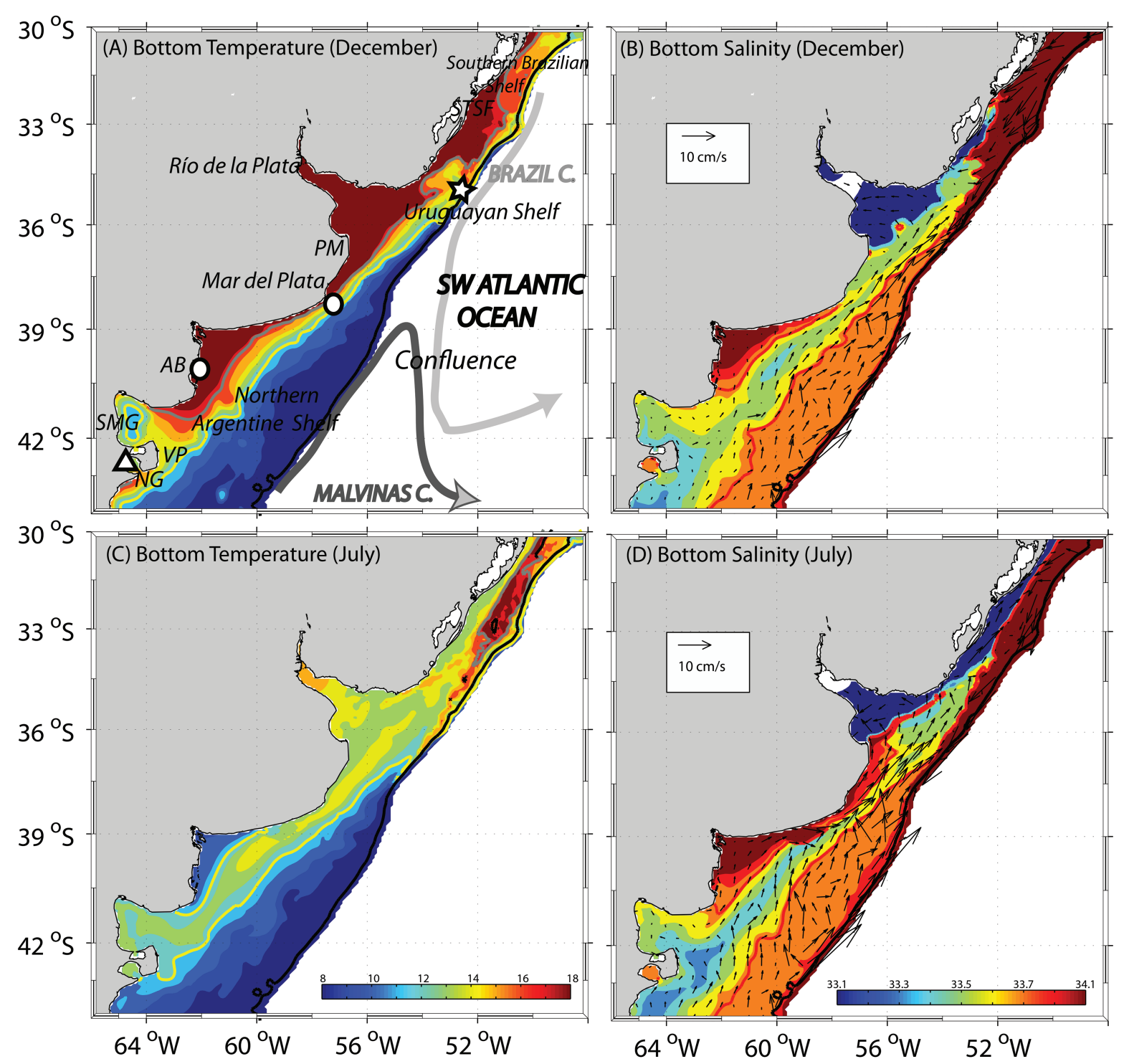

Fig. 1. Schematic representation of the depth-averaged ocean circulation in the Southwestern Atlantic Ocean (adapted from Matano et al., 2010) showing the geographical locations of tagging of Galeorhinus galeus [Triangle, Nuevo Gulf (NG),

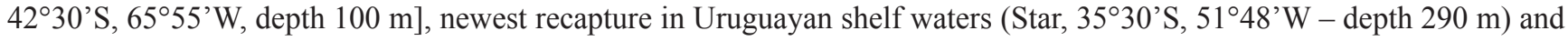
the two old recapture sites (Circle, Mar del Plata, $38^{\circ} 24^{\prime} \mathrm{S}, 57^{\circ} 18^{\prime} \mathrm{W}$, depth $40 \mathrm{~m}$ and Canal Culebra, $40^{\circ} 24^{\prime} \mathrm{S}, 62^{\circ} 06^{\prime} \mathrm{W}$ depth $15 \mathrm{~m}$, Irigoyen et al., 2015). Additional geographical locations are indicated with acronyms: SMG = San Matías Gulf, $\mathrm{VP}=$ Valdés Peninsula, $\mathrm{AB}=$ Anegada Bay, $\mathrm{PM}=$ Punta Médanos, $\mathrm{STSF}=$ Subtropical Shelf Front. The thick curved lines represent the path of the major ocean currents. The black line is the $200 \mathrm{~m}$ isobath. Colours indicate bottom temperature (a, c) and bottom salinity $(b, d)$ and black arrows indicate the bottom shelf circulation extracted from a numerical model (Palma et al., 2008). The yellow and gray lines in the left panels indicate the 11 and $17^{\circ} \mathrm{C}$ isotherms respectively. The red and cyan lines in the right panels indicate the 33.93 and 33.5 isohalines.

\section{Results}

Ninety-four school sharks (Fig. 2C) were captured, 75 females and 19 males. The size length distribution was unimodal in both sexes, the total length (TL) of female ranged from 90 to $150 \mathrm{~cm}$ of TL with a peak in $120 \mathrm{~cm}$ of $\mathrm{TL}$, and in male, the TL ranged between 100 and $130 \mathrm{~cm}$ of TL with a mode in $120 \mathrm{~cm}$ TL (Fig. 2C). The surface water temperature was $18^{\circ} \mathrm{C}$.
A $112 \mathrm{~cm}$ TL female (\#tag 4165, Figs. 2A-B) was recaptured in Uruguayan Shelf waters on August 17, 2015 during a bottom longline fishery operation at $140 \mathrm{~km}$ off the coast at a depth around $290 \mathrm{~m}\left(35^{\circ} 18^{\prime} \mathrm{S}, 52^{\circ} 30^{\prime} \mathrm{W}\right.$, near the limit with the Southern Brazilian Shelf). An onboard observer of Dirección Nacional de Recursos Acuáticos (DINARA, Uruguay) reported the recapture. The specimen had been tagged in Nuevo Gulf ( $\sim 2^{\circ} 30^{\prime}$ 'S, Argentina) during February 15, 2015. At the moment of capture, it 
measured $110 \mathrm{~cm} \mathrm{TL}$. After 183 days, the recapture location implied that the shark travelled a minimum distance of approximately $1425 \mathrm{~km}$ (Fig. 1A). According to the female maturity curve in the southern area of distribution [juveniles (TL until $118 \mathrm{~cm} \mathrm{LT})$, sub-adult $(118 \mathrm{~cm}>\mathrm{TL}$ $<129 \mathrm{~cm}$ ), adult (TL $>129 \mathrm{~cm})$, Lucifora et al., 2004], and size at $50 \%$ maturity at $\sim 124 \mathrm{~cm}$ TL (Chiaramonte, 2000; Lucifora et al., 2004), the recaptured specimen is a sub-adult.
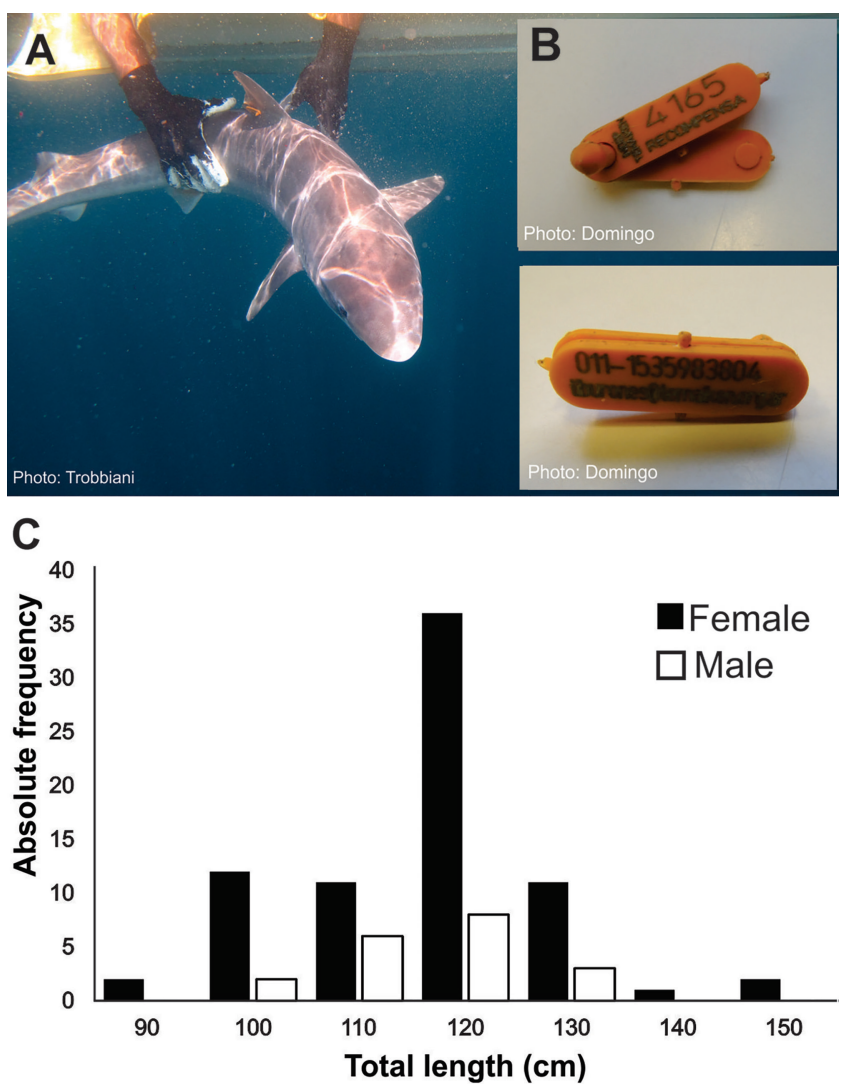

Fig. 2. A) Releasing of a tagged Galeorhinus galeus, B) the recaptured tag on August 17, 2015, and C) length size distribution of school sharks captured and tagged in Nuevo Gulf ( 42 ${ }^{\circ} 30^{\prime}$ S, Argentina) during February 15, 2015.

\section{Discussion}

There is substantial evidence elsewhere that G. galeus is capable of migrating over significant distances across the open ocean. In the Southwestern Pacific several long distance displacements $(>500 \mathrm{~km})$ have been observed including one reaching $4940 \mathrm{~km}$ (Hurst et al., 1999). In the Northeast Atlantic, specimens tagged off England and Ireland have been recaptured as far away as off northern Iceland, a 2,641 $\mathrm{km}$ journey (Stevens, 1990). In SWA waters, the spatial and temporal distribution patterns of this species are not well known, but the migration recorded in this study $(\sim 1,425$ $\mathrm{km})$ is within the range observed in other temperate shelves, and confirm the possibility of a long seasonal migration of a single population of the species as posited by Vooren (1997) and Lucifora et al. (2004). These results concur with genetic analyses that revealed no significant population structure among individuals from San Matías Gulf, Anegada Bay, and Punta Médanos (Fig. 1A; Cuevas et al., 2016).

At large scale, the school shark distribution within the SWA extends from coast of Rio Grande do Sul State $\left(28^{\circ} \mathrm{S}\right.$, Brazil; Bellisio et al., 1979) to Península San Julián $\left(49^{\circ} \mathrm{S}\right.$, Argentina, Chiaramonte, 2015), mainly associated to Bonaerensean Biogeographic District (Menni et al., 2010). In the Southern Brazilian Shelf waters the school shark occurs during austral winter months (from June to September) mainly between 100 and $350 \mathrm{~m}$ deep on the continental slope and it is absent in spring and summer months (Ferreira, Vooren, 1991; Peres, Vooren, 1991; Klippel et al., 2016). In that region, the sea surface temperature (SST) is a better predictor for G. galeus occurrence than depth, salinity or chlorophyll, it prefers SST below $17^{\circ} \mathrm{C}$ with maximum occurrence around $12.5-15^{\circ} \mathrm{C}$ (Klippel et al., 2016). After or during the end of winter, G. galeus starts a southward migration to Uruguayan and Northern Argentine Shelf waters (Marín, Puig, 1987). In the inner shelf (depth $<50 \mathrm{~m}$ ), under the influence of the Río de la Plata freshwater discharge, its spring occurrence is associated with higher salinities (33.134.1 ) and intermediate temperatures ( $\mathrm{T}$ from 11.7 to $16.5^{\circ} \mathrm{C}$ ) (Jaureguizar et al., 2006, 2015). On the Northern Argentine Shelf, the school shark occurs during spring (OctoberDecember, $\mathrm{T}$ from 12 to $13^{\circ} \mathrm{C}$, mainly males) and early autumn (mainly females), and is absent during summer ( $\mathrm{T}>$ $16-17^{\circ} \mathrm{C}$ ) and winter (Lucifora et al., 2004).

These early studies indicate that the $\mathrm{T}$ and $\mathrm{S}$ ranges that the school shark inhabits coincide with the warmest water mass of the Subantarctic Shelf Waters (Fig. 1), also called Mid Continental Shelf Water (Piola et al., 2000; Lucas et al., 2005, with $33.5<\mathrm{S}<33.7$; Palma et al., 2008). The mean salinity (Figs. 1B-C) and temperature (Figs. 1A-C) distribution patterns at the bottom during summer (January) and winter (July) generated by a numerical model are in good agreement with school shark early observations within the SWA shelf waters. The school shark migration could be explained by predominance of salty (33-34) and warm $\left(12^{\circ}-17^{\circ} \mathrm{C}\right)$ waters in the inner-middle shelf related to a physiological response as a function of salinity and thermal tolerance. In this sense, the southward migration from Southern Brazil Shelf waters during late spring could be related to warm-salty intrusions $\left(\mathrm{T}>16^{\circ} \mathrm{C} ; \mathrm{S}>34.72\right)$ derived from Subtropical and Subantarctic shelf waters mixtures. Similarly, the summer emigration from Anegada Bay to southern and deeper waters of Northern Argentine Shelf(Elias et al., 2005; Irigoyen et al., 2015) can be ascribed to the excessive heating of the shallow coastal waters. The subsequent northward migration could be associated to excessive cooling of the southern shelf waters during fall and winter. Consequently, the seasonal variation in school shark abundance along the SWA shelf might be related to movements of the species within a specific range of $\mathrm{T}$ and $\mathrm{S}$ that in turn is associated with the seasonal variability of 
the water masses over the shelf. This may allow individuals to keep, within the saline tolerance, a specific range of temperatures within the shelf water as adaptive strategy to reduce the gestation period in adult females, as suggested for other chondrichthyans (Economakis, Lobel, 1998; Robbins, 2007; Hight et al., 2012; Elisio et al., 2016). The long northward migration $(1,425 \mathrm{~km})$ of a female from February to August reported in this study seems to support the above hypothesis.

\section{Acknowledgments}

The authors want to express their gratitude to the Fundation Temaiken authorities and Bioparque Temaiken staff for supporting the 2015 tagging program. We also are grateful to the onboard observer of DINARA for the recapture report, and to Domingo Andrés and Rodrigo Forselledo from Pelagic Resource Laboratory - DINARA by the communication of report and suggestions on manuscript. To the fishermens Mariano Cuestas, Miguel Lupiano, Oscar Trobbiani, and Gustavo Zamora for their help on field activities. We especially want to acknowledge a huge friend, Dr. L. Lucifora, and the reviewers for their valuable suggestions and editorial comments that improved the manuscript. Support for ED Palma came from Agencia Nacional de Promoción Científica y Tecnológica (ANCYPTGrant PICT16-0557) and Universidad Nacional del Sur (Grant 24/F053). INIDEP Contribution \# 2092.

\section{References}

Bellisio NB, López RB, Torno A. Peces marinos patagónicos. Buenos Aires: Subsecretaría de Pesca; 1979.

Chabot CL. Microsatellite loci confirm a lack of population connectivity among globally distributed populations of the tope shark Galeorhinus galeus (Triakidae). J Fish Biol. 2015; 87(2):371-85. Available from: http://dx.doi.or/10.1111/ jfb. 12727

Chiaramonte GE. Biología y pesquería del tiburón vitamínico Galeorhinus galeus (Linnaeus, 1758) (Pisces Elasmobranchii: Triakidae) en Puerto Quequén. [Graduation]. Buenos Aires: Universidad Nacional de Buenos Aires; 2000.

Chiaramonte GE. El cazón o tiburón vitamínico Galeorhinus galeus (Linnaeus, 1758) (Pisces Elasmobranchii: Triakidae) en Argentina [PhD Thesis]. Buenos Aires: Universidad Nacional de Buenos Aires; 2015.

Compagno LJV, Dando D, Fowler S. A field guide to the sharks of the world. London: Harper Collins Publishing Ltd.; 2005.

Cuevas JM, García M, Cuello M, Di Giacomo E, Jaureguizar AJ, Milessi AC. Identificación de los stocks del cazón (Galeorhinus galeus) en el sector norte del Mar Argentino, utilizando el marcador mitocondrial NADH2. BAG J Basic Appl Genet. 2016; 27(1):156.

Ebert DA, Fowler S, Compagno L, Dando M, editors. Sharks of the World: a Fully Illustrated Guide. Plymouth: Wild Nature Press; 2013.
Economakis AE, Lobel PS. Aggregation behavior of the grey reef shark, Carcharhinus amblyrhynchos, at Johnston Atoll, Central Pacific Ocean. Environ Biol Fishes. 1998; 51(2):129-39.

Elias I, Rodriguez A, Hasan E, Reyna MV, Amoroso R. Biological observations of the tope shark, Galeorhinus galeus, in the northern Patagonian gulfs of Argentina. J Northw Atl Fish Sci. 2005; 35:261-65.

Elisio M, Colonello JH, Cortés F, Jaureguizar AJ, Somoza GM, Macchi GJ. Aggregations and reproductive events of the narrownose smooth-hound shark, Mustelus schmitti, in relation to temperature and depth in coastal waters of the southwestern Atlantic Ocean (38-42 $\left.{ }^{\circ} \mathrm{S}\right)$. Mar Freshwater Res. 2016; 38(4):732-42. Available from: http://dx.doi.or/10.1071/ MF15253

Ferreira BP, Vooren CM. Age, growth, and structure of vertebra in the school shark Galeorhinus galeus (Linnaeus, 1758) from Southern Brazil. Fish Bull. 1991; 89(1):19-31.

Hight BV, Lowe CG. Elevated body temperatures of adult female leopard sharks, Triakis semifasciata, while aggregating in shallow nearshore embayments: Evidence for behavioural thermoregulation? J Exp Mar Bio Ecol. 2007; 352(1):114-28.

Hurst RJ, Baglet NW, McGregor GA, Francis MP. Movements of the New Zealand school shark, Galeorhinus galeus, from tag returns. N Z J Mar Freshwater Res. 1999; 33(1): 29-48. Available from: http://dx.doi.or/10.1080/00288330.1999.9516854

Irigoyen A, Sibbald C, Cuestas M, Cristiani F, Trobbiani G. Patrones estacionales de abundancia en el Golfo Nuevo y migración a lo largo de la plataforma Argentina de cazones (Galeorhinus galeus [Linnaeus 1758]) y gatopardos (Notorynchus cepedianus [Péron 1807]) (Argentina). Ecología Austral. 2015; 25(2):144-48.

Jaureguizar AJ, Cortés F, Milessi AC, Cozzolino E, Allega L. A trans-ecosystem fishery: environmental effects on the smallscale gillnet fishery along the Río de la Plata boundary. Estuar Coast Shelf Sci. 2015; 166(A):92-104. Available from: http:// doi:10.1016/j.ecss.2014.11.003

Jaureguizar A, Menni R, Lasta C, Guerrero R. Fish assemblages of the Northern Argentine Coastal System: spatial patterns and their temporal variations. Fish Oceanogr. 2006; 15(4):326-44. Available from: http://dx.doi.or/10.1111/j.13652419.2006.00405.x

Klippel S, Amaral S, Vinhas L. Development and evaluation of species distribution models for five endangered elasmobranchs in southwestern Atlantic. Hydrobiologia. 2016; 779(1):11-33. Available from: http://dx.doi.or/10.1007/s10750-016-2796-5

Lucas AJ, Guerrero RA, Mianzán H, Acha EM, Lasta CA. Coastal oceanographic regimes of northern Argentine continental shelf $\left(34^{\circ}-43^{\circ} \mathrm{S}\right)$. Estuar Coast Shelf Sci. 2005; 65(3):405-20.

Lucifora OL, Menni RC, Escalante, AH. Reproductive biology of the school shark, Galeorhinus galeus, off Argentina: support for a single south western Atlantic population with synchronized migratory movements. Environ Biol Fishes. 2004; 71(2):199-209.

Marín Y, Puig P. La pesquería de tiburones con palangre desde el puerto de La Paloma (1975 - 1985). Publ Com Téc Mix Fr Mar. $1987 ; 3: 117-23$. 
Matano RP, Palma ED, Piola AR. The influence of the Brazil and Malvinas Currents on the Southwestern Atlantic Shelf circulation. Ocean Sci. 2010; 6:983-95.

Matano RP, Schlax MG, Chelton DB. Seasonal variability in the southwestern Atlantic. J Geophys Res Oceans. 1993; 98(C10):18027-35. Available from: http://dx.doi. or/10.1029/93JC01602

Menni CR, Jaureguizar AJ, Stehmann MFW, Lucifora LO. Marine biodiversity at the community level: zoogeography of sharks, skates, rays and chimaeras in the southwestern Atlantic. Biodivers Conserv. 2010; 19(3):775-96. Available from: http:// dx.doi.or/10.1007/s10531-009-9734-Z

Nion H. La pesquería de tiburones en Uruguay con especial referencia al cazón (Galeorhinus galeus Linnaeus 1758). In: Shotton R, editor. Case studies of the management of elasmobranch fisheries. Rome: FAO; 1999. (Fisheries Technical Paper; no 378, pt. 1).

Palma ED, Matano RP, Piola AR. A numerical study of the Southwestern Atlantic Shelf circulation: Stratified ocean response to local and offshore forcing. J Geophys Res Oceans. 2008; 113(C11):C11010. Available from: http://dx.doi. or/10.1029/2007JC004720

Peres MB, Vooren CM. Sexual development, reproductive cycle, and fecundity of the school shark Galeorhinus galeus off southern Brazil. Fish Bull. 1991; 89(4):655-67.

Piola AR, Campos EJD, Möller OO, Jr, Charo M, Martinez CM. Subtropical shelf front off eastern South America. J Geophys Res Oceans. 2000; 105(C3):6566-78.

Piola AR, Matano RP. The South Atlantic Western Boundary Currents Brazil/Falkland (Malvinas) Currents. In: Steele, JM, Thorpe SA, Turekian KK, editors. Encyclopedia of Ocean Sciences. New York: Elsevier; 2001. p.340-49.
Robbins RL. Environmental variables affecting the sexual segregation of great white sharks Carcharodon carcharias at the Neptune Islands South Australia. J Fish Biol. 2007; 70(5):1350-64.

Stevens JD. Further results of a tagging study of pelagic sharks in the north-east Atlantic. J Mar Biol Assoc UK. 1990; 70(4):707-20.

Vooren CM. Demersal elasmobranchs. In: Seeliger U, Odebrecht C, Castello JP, editors. Subtropical Convergence Environments: The Coast and Sea in the Southwestern Atlantic. Heidelberg: Springer-Verlag; 1997. p.141-46.

Walker T. Galeorhinus galeus fisheries of the world. In: Shotton R, editor. Case Studies of the Management of Elasmobranch Fisheries. Rome: FAO; 1999. (FAO Fisheries Technical Paper; no 378, pt 2).

Walker TI, Cavanagh RD, Stevens JD, Carlisle AB, Chiaramonte GE, Domingo A, Ebert DA, Mancusi CM, Massa A, McCord M, Morey G, Paul LJ, Serena F, Vooren CM. Galeorhinus galeus. The IUCN Red List of Threatened Species; 2006; doi. org/10.2305/IUCN.UK.2006.RLTS.T39352A10212764.en 